\title{
FRANCHISE \\ SEBAGAI SALAH SATU BIDANG USAHA INDUSTRI
}

\author{
Oleh : Endang Supardi *) \\ Sri Mulyati **)
}

\begin{abstract}
Abstrak
Kesuksesan suatu perusahaan tidak selalu berangkat dari barang atau jasa yang spektakuler dan inovatif. Sering kali seorang wirausaha hanya memasuki celah pasar yang kosong dan membuat langkah tepat untuk menyediakan barang atau jasa yang biasa kepada pelanggan yang menerimanya. Franchise memberikan bentuk unik pada kesempatan bisnis, melibatkan pengaturan yang formal dan suatu tatanan hubungan yang memerintahkan cara suatu bisnis harus dijalankan. Perusahaan franchise biasanya memberi sistem (franchisee) tersebut dengan nama, logo, produk, prosedur pengoperasian dan lain-lain. Kita ingin menekankan bahwa franchise telah membuat kepemilikan bisnis memungkinkan bagi siapa saja yang telah dapat memasuki bisnis keluarga, atau dengan kata lain tidak akan pernah melepaskan diri dari pekerjaan yang digaji. Dalam hal ini, franchise telah memberikan sumbangan keberhasilan bagi banyak para wirausaha bidang industri makanan dan minuman. Untuk dapat melaksanakan usaha franchise, terlebih dahulu kita harus mengetahui konsep francise itu sendiri karena usaha ini melibatkan franchisor dan franchisee. Seperti usaha lainnya, franchise memiliki kelebihan dan kekurangan yang harus dipahami oleh franchisor dan franchisee.
\end{abstract}

Kata kunci: Franchise, usaha industri.

\section{Pendahuluan}

Terminologi franchising dapat diartikan dalam berbagai cara. Franchising adalah suatu sistem pemasaran yang berkisar pada perjanjian sah antara dua pihak yang salah satunya (franchisee) diberi hak istimewa untuk menjalankan bisnis sebagai pemilik pribadi, tetapi dengan syarat perusahaan dijalankan menurut metode dan terminologi yang dispesifikasikan oleh pihak yang lain (franchisor).

Nilai potensial dalam perjanjian franchise ini dibatasi oleh hak-hak yang ada di dalam perjanjian tersebut. Perjanjian resmi ini dikenal sebagai kontrak franchise, dan hak yang terdapat di dalamnya disebut

*) Drs. Endang Supardi, M.Si. Dosen Jurusan Pendidikan Ekonomi FPIPS-UPI

**) Sri Mulyati, S.Pd, Stap Penganjar Bidang Studi IPS SLTP 2 Lembang 
franchise. Terminologi yang umumnya digunakan untuk menggambarkan hubungan antara franchisor dan franchisee adalah franchise dalam bentuk produk dan merk. Saluran pompa bensin, dealer mobil, soft drink (minuman dingin) botolan adalah contoh-contoh yang dapat dilihat.

Master licensee (penerima ijin utama) adalah perusahaan atau seseorang yang mempunyai hubungan kontrak yang berkelanjutan dengan seorang franchisor untuk menjual franchisenya. Strategi franchising lainnya yang memberikan kegunaan bermacam-macam adalah kepemilikan unit berganda (multiple-unit ownership), yaitu franchise tunggal yang memiliki lebih dari satu unit bisnis franchise.

Piggyback franchising ditujukan untuk pelaksanaan franchise retail yang menggunakan fasilitas fisik dari pemilik toko yang ditempatinya. Contoh dari piggyback franchising adalah perusahaan kue yang menjalankan bisnisnya di dalam gerai makanan cepat saji.

\section{Struktur Industri Franchise}

Tiga tipe atau tingkatan dari sistem franchise menawarkan berbagai hubungan antara wirausaha dan franchisor. Pada level pertama, produsen (franchisor) memberikan franchise kepada penjual. Sistem seperti ini biasa digunakan di dalam industri minuman dingin.

Dalam bentuk pengaturan yang kedua, penjualnya adalah si franchisor. Sistem ini berkisar pada supermarket dan toko barang dagangan umum.

Sistem franchise yang ketiga ini, sistem yang sering kali digunakan adalah si franchisee. Dealer mobil dan stasiun pompa bensin adalah prototipe sistem ini.

\section{Kelebihan Usaha Franchise}

Satu penjelasan tentang kegagalan franchise yang rendah adalah bahwa kebanyakan franchisor menyeleksi dengan sungguh-sungguh ketika memberikan franchisenya. Banyak franchisee potensial yang memenuhi syarat dalam segi keuangannya telah ditolak.

Ada tiga tambahan dan lebih spesifik, alasan mengapa kesempatan franchise menarik, yaitu: 1). Pelatihan, 2). Bantuan finansial, 3). Keuntungan operasi. Tentu saja, semua franchise tidak sama kuatnya dalam semua aspek. Tetapi beberapa kelebihan franchise memotivasi orang untuk mempertimbangkan perjanjian franchise. 
1). Pelatihan

Lingkungan produk dan tipe bisnis mempengaruhi jumlah dan tipe pelatihan yang dipelukan oleh franchise.

2). Bantuan Keuangan

Biaya untuk memulai suatu bisnis yang independen kadangkala tinggi, dan wirausaha pada umumnya memiliki sumber modal yang terbatas. Dengan bekerjasama dengan organisasi franchising, franchisee yang memiliki aspirasi dapat memperbesar kesempatannya untuk mendapat bantuan keuangan.

Jika Organisasi franchising mempertimbangkan lamaran dengan prospek yang sesuai dengan probabilitas sukses yang tinggi, hal itu sering kali memperpanjang memberi bantuan dari segi keuangan.

3). Keuntungan Operasi

Kebanyakan barang dan jasa franchise dikenal dan diterima secara luas. Sebagai contoh, konsumen akan dengan segera membeli hamburger McDonald's atau es krim Baskin Robbins, karena mereka mengetahui reputasi produk ini.

Para wirausaha yang memiliki perjanjian franchising mendapat hak untuk menggunakan merek atau logo milik franchisor yang telah dipromosikan secara naional. Hal ini dilakukan untuk mengidentifikasi perusahaan lokal dengan barang atau jasa yang telah dikenal secara luas. Tentu saja, nilai pengidentifikasian produk berbeda dengan bentuk barang atau jasa dan luasnya sebaran promosi yang telah diterimanya. Dalam kasus tertentu, franchisor memelihara nilai dari namanya dengan terus beriklan dan berpromosi.

Keberadaan produk dan metode yang telah terbukti, bagaimana juga tidak menjamin bahwa suatu franchise akan sukses. Franchisor yang mempunyai catatan kesuksesan pengoperasian perusahaannya membuktikan bahwa sistem dapat digunakan dan telah berhasil di berbagai tempat.

\section{Kekurangan Franchising}

Franchising seperti sekeping mata uang yang memiliki dua buah sisi. Kita telah menyajikan sisi possitif franchising tetapi kita harus pula mengamati sisi negatifnya. Pada khususnya, terdapat tiga kekurangan di dalam bentuk bissnis franchise, yaitu:

1). Biaya Franchise

Biaya franchise mempunyai beberapa komponen yang semuanya harus dikenali (pada umumnya upah yang lebih tinggi yang diminta

*) Drs. Endang Supardi, M.Si. Dosen Jurusan Pendidikan Ekonomi FPIPS-UPI

**) Sri Mulyati, S.Pd, Stap Penganjar Bidang Studi IPS SLTP 2 Lembang 
oleh franchisor terkenal). Berikut ini adalah empat komponen khas dari biaya franchise:

a. Upah franchise awal

Total biaya franchise dimulai dengan upah awal franchise yang dapat berkisar dari ratusan sampai ribuan dollar.

b. Kas yang diinvestasikan

Terdapat biaya yang signifikan yang terlibat di dalam menyewa atau membangun gerai dan melengkapinya dengan peralatan lainnya. Juga premi asuransi, upah untuk pengesahannya, dan beban permulaan lainnya yang harus dibayar.

c. Pembayaran royalti

Praktik yang umum adalah franchisor menerima pembayaran royalti yang berkelanjutan berdasarkan persentase pendapatan kotor franchise.

d. Biaya periklanan

Banyak franchisor meminta kontribusi dari pihak franchisee untuk biaya iklan dan promosi franchisenya.

Jika para wirausaha dapat menghasilkan penjualan pada tingkatan yang sama dengan mendirikan bisnis yang independen, mereka akan menghemat upah franchise dan beberapa biaya lainnya.

\section{Mengevaluasi Kesempatan usaha Pranchise}

\section{Pembatasan Pengoperasian Bisnis}

Franchisor dapat dimengerti jika mempedulikan image franchise mereka. Oleh karena itu, mereka berusaha untuk mengendalikan perilaku franchisee pada aspek teertentu dalam bisnis franchisenya. Sehingga, franchisee dibatasi kemampuannya untuk menggunakan pertimbangan bisnis secara pribadi. Bentuk pengendalian tersebut sering kali dilakukan franchisor meliputi:

a. Membatasi daerah penjualan

b. Meminta daftar lokasi untuk gerai pengecernya dan memaksakan persyaratan yang berkaitan dengan penampilan gerainya.

c. Membatasi barang dan jasa yang ditawarkan untuk dijual.

d. Membatasi periklanan dan jam kerja.

\section{Hilangnya Kebebasan}

Banyak orang meninggalkan pekerjaannya untuk berwirausaha, karena mereka tidak menyukai pekerjaan dibawah supervisi dan pengendalian langsung dari orang lain. Selama menjalani kerja sama

*) Drs. Endang Supardi, M.Si. Dosen Jurusan Pendidikan Ekonomi FPIPS-UPI

**) Sri Mulyati, S.Pd, Stap Penganjar Bidang Studi IPS SLTP 2 Lembang 
franchise, ada orang yang mungkin menemukan bahwa pola supervisi yang berbeda telah diterapkan. Franchisee menyerahkan sejumlah kebebasan yang agak banyak dalam menandatangani perjanjian franchise.

Meskipun pengaruh franchisor pada operasi bisnis dapat membantu didalam memastikan kesuksesan perusahaan, tingkat pengendalian yang diusahakan mungkin tidak menyenangkan bagi seorang wirausaha yang mencintai kebebasan.

Para wirausaha harus mengakui bahwa mereka dapat kehilangan hak pada franchisenya jika mereka tidak mematuhi standar kinerja atau gagal membayar royalti. Ditambah lagi tidak terdapat jaminan bahwa sebuah franchise akan diperbaharui setelah masa kontraknya yang biasanya berumur 15-20 tahun.

Mengevaluasi kesempatan usaha franchise dimulai dengan :

\section{$>$ Menyeleksi Kandidat Franchise yang Potensial}

Dengan tumbuhnya franchise selama bertahun-tahun, tugas awal untuk menempatkan franchise secara tepat menjadi lebih mudah. Pengamatan yang dilakukan oleh diri sendiri sering kali menimbulkan ketertarikan atau kesadaran yang dimulai dengan pencarian iklan atau artikel di surat kabar atau majalah.

\section{$>$ Menginvestigasi Kandidat Franchise}

Meluncurkan bisnis franchise biasanya melibatkan investasi keuangan yang besar, biasanya dalam ribuan dollar. Untuk memelihara komitmrn yang diminta oleh franchise itulah dibutuhkan investigasi yang teliti karena hubungan bisnis tersebut diharapkan dapat berlangsung selama periode tahun tertentu.

Proses evaluasi bersifat dua arah, yaitu evaluasi dari pihak franchisor dan franchisee. Pihak franchisor berkeinginan untuk memeriksa franchisee dan franchisee secara jelas berkeinginan untuk mengevaluasi franchisor dan bentuk kesempatan yang ditawarkan.

Dalam mengevaluasi franchising, calon wirausaha dapat melakukan berbagai upaya untuk mendapatkan informasi mengenai franchising. Pada dasarnya, terdapat tiga informasi yang seharusnya ditekankan, yaitu: 1). Kebebasan dari pihak ketiga dan sumber informasi, 2). Pihak franchisor itu sendiri, 3). Franchisee yang ada sekarang maupun yang sebelumnya.

*) Drs. Endang Supardi, M.Si. Dosen Jurusan Pendidikan Ekonomi FPIPS-UPI

**) Sri Mulyati, S.Pd, Stap Penganjar Bidang Studi IPS SLTP 2 Lembang 


\section{Memehami Hubungan Franchisor dan Franchisee Sudut Pandang Franchisor}

Mengevaluasi usaha franchise dari sudut pandang franchisor, setidaknya terdapat tiga keuntungan yang dapat diidentifikasikan:

1) Pengurangan persyaratan modal

Franchise memungkinkan sebuah perusahaan untuk memperluas usahanya tanpa mencairkan modal. Melalui pengaturan upah dan royalti, perusahaan yang terlibat didalam franchise pada hakikatnya meminjam modal daripada franchise untuk pengembangan salurannya. Oleh karena itu mempunyai persyaratan modal yang lebih kecil daripada memiliki rangkaian secara keseluruhan.

2) Meningkatkan motivasi dalam manajemen

Franchisee sebagai pemilik, lebih sangat termotivasi daripada karyawan yang digaji, karena insentif laba dan minat akan hak-hak mereka didalam bisnis tersebut. Sejak franchise didesentralisasikan, franchisor juga tidak mudah terpengaruh oleh usaha pengorganisasian tenaga kerja bila dibandingkan dengan organisasi yang tersentralisasi.

3) Kecepatan ekspansi perusahaan

Franchise membiarkan bisnis memasuki pasar lebih cepat daripada jika perusahaan menggunakan sumbernya sendiri untuk memasuki pasar.

Terdapat pula kekurangan yang berkaitan dengan franchise dari sudut pandang franchisor. Setidaknya terdapat tiga kekurangan yaitu:

- Pengurangan pengendalian

Pengendalian oleh seorang franchisor atas bisnisnya berkurang karena franchisee bukan karyawan. Ini adalah permasalahan besar bagi franchisor.

- Pembagian laba

Hanya bagian laba tertentu yang menjadi milik franchisor.

- Meningkatkan pendukung operasi

Pada umumnya terdapat lebih banyak biaya yang berhubungan dengan pemeliharaan hubungan franchise yang sedang berlangsung, khususnya didalam menyediakan jasa hukum dan akuntansi bila dibandingkan dengan organisasi yang tersentralisasi.

\section{Hubungan Franchisor dan Franchisee}

Gambaran dasar dari hubungan franchisor dan franchisee terlihat dalam kontrak franchise yang ada. Kontrak ini biasanya sebuah dokumen yang komplek, terdiri dari banyak halaman. Karena pentingnya dokumen

*) Drs. Endang Supardi, M.Si. Dosen Jurusan Pendidikan Ekonomi FPIPS-UPI

**) Sri Mulyati, S.Pd, Stap Penganjar Bidang Studi IPS SLTP 2 Lembang 
tersebut sebagai dasar hukum bagi bisnis franchise, kontrak franchise seharusnya tidak ditanda tangani oleh franchisee tanpa konsultasi hukum terlebih dahulu. Seorang pengacara dapat mengantisipasi sedikit masalah dan mencatat adanya ketentuan yang tidak disukai dari kontrak tersebut.

Salah satu ketentuan terpenting dari kontrak franchisee adalah persyaratan yang berhubungan dengan penghapusan dan perpindahan franchise, calon franchisee seharusnya berhati-hati terhadap persyaratan kontrak yang mengandung kebijaksanaan penundaan yang tegas secara keseluruhan. Dan hak franchisee untuk menjual bisnis pada pihak ketiga harus ditentukan syarat yang jelas, dan hak franchisee untuk memperbaharui kontrak setelah bisnis yang dibangun tersebut mencapai tingkat kesuksesan operasi yang di harapkan juga harus disebutkan dalam kontrak secara jelas.

\section{Penipuan Dalam Franchise}

Tiap industri mempunyai operasi yang tidak jujur dan tidak terkecuali bagi franchise. Majalah entrepreneur menganjurkan 10 tanda peringatan adanya ketidak beresan pada franchise, sebagai berikut:

1). Sindrom Rolls Royce. Sewaan, pemakaian perhiasan yang berlebihan dirancang untuk meyakinkan anda akan kesuksesannya. Orang-orang ini berbau uang,dan kita berharap ini terjadi pada kita. Pemecahannya: memeriksa laporan keuangan pada dokumen yang ditawarkan, perusahaan tersebut harus diaudit.

2). Adanya Paksaan. Franchisor membuat anda merasa menjadi pemimpin yang tidak berharga dan ragu-ragu jika tidak segera mengambil tindakan. Pemecahannya: Gunakan waktu anda untuk mengenali desakan yang menggunakan teknik penutup penjualan yang kasar.

3). Transaksi Dibayar Tunai. Franchisor menginginkan anda membayar secara tunai atas dasar rasa saling percaya. Tapi sebaliknya anda melakukan pemeriksaan pada perusahaan bukan pada perorangan.

4). Kesombongan. Mereka mengecoh kita agar memikirkan hal-hal yang besar dan tidak realistis. Padahal yang dibutuhkan adalah hal-hal yang kecil dan realistis. Jadi anda hendaknya membuat rencana bisnis yang realistis dan jadilah pemikir akan hal-hal kecil saja.

5). Klaim Akan Sejumlah Uang. Mereka mengklaim sejumlah uang yang berlebih sebagai keuntungan yang didapat. Jadi sebaiknya anda baca UFOC dan temukanlah lima pemilik yang memperoleh klaim atas pendapatannya.

*) Drs. Endang Supardi, M.Si. Dosen Jurusan Pendidikan Ekonomi FPIPS-UPI

**) Sri Mulyati, S.Pd, Stap Penganjar Bidang Studi IPS SLTP 2 Lembang 
6). Mimpi Seorang Pemalas. Mereka menawarkan harpan yang besar kepada anda dalam menjalankan bisnis yang mudah tetapi mendapatkan keuntungan yang besar, sebaiknya anda bekerja secara jujur dan mendapat imbalan.

7). Aliran Pengungkapan. Banyak ungkapan-ungkapan yang dikeluarkan oleh mereka tetapi tidak sesuai dengan kenyataan.

8). Tipuan Registrasi. Mencari alasan dalam negara bagian (propinsi) yang mengharuskan registrasi franchise dan perusahaan tidak terdaftar. Pada dasarnya tidak memerlukan segala sesuatu yang berkaitan dengan registrasi.

9). Lokasi. Banyak lokasi yang menguntungkan yang ditawarkan kepada anda, tetapi lebih baik anda periksa sendiri lokasi-lokasinya ditawarkan tersebut.

10).Franchisor yang Bermodal Sedikit. Banyak franchisor yang mengaku mempunyai modal banyak padahal yang ia miliki sedikit. Jadi sebaiknya ambilah UFOC dan bawalah kepada akuntan anda dan pelajari sumber apa yang dipunyai oleh franchisor untuk mendukung kewajiban kontraktualnya.

Kemungkinan adanya rencana tipuan membutuhkan kewaspadaan bagi calon franchisee. Hanya penyelidikan yang hati-hati pada perusahaan dan produknya yang dapat membedakan antara operator tipuan dan kesempatan franchise yang sah.

\section{Kunci Sukses Dalam Bisnis Industri Franchise}

Pengungkapan dokumen merupakan pernyataan lengkap yang berisi informasi mengenai keuangan, pengalaman franchisor, ukuran dan menginformasikan pada franchisee yang berpotensi tentang batasan, biaya dan syarat pembaruan atau penundaan suatu franchise.

Setiap perusahaan yang mempertimbangkan waralaba sebagai metode pertumbuhan dan distribusi atau individu yang mempertimbangkan waralaba sebagai meetode untuk memulai bisnis sendiri, harus memiliki kunci sukses bagi industri ini.

Menurut Ir. H. Muharam,BH, SM Franchise.com, Januari 2003, ada 17 kunci sukses bagi usaha waralaba, yaitu:

1) Usaha yang dijalankan merupakan suatu prototipe usaha (atau rangkaian toko) yang terbukti sukses.

2) Memiliki tim manajemen yang memadai.

3) Memiliki modal yang memadai untuk memulai dan mengembangkan suatu program waralaba.

*) Drs. Endang Supardi, M.Si. Dosen Jurusan Pendidikan Ekonomi FPIPS-UPI

**) Sri Mulyati, S.Pd, Stap Penganjar Bidang Studi IPS SLTP 2 Lembang 
4) Memiliki identitas dagang yang khas, berbeda dan dilindungi oleh hukum.

5) Memiliki metode operasi dan manajemen.

6) Memiliki program pelatihan yang sistematis dan aplikatif bagi franchisee.

7) Memilki staff pendukung lapangan yang terlatih dan profesional.

8) Memiliki dokumen sah yang komprehensif yang mencerminkan strategi bisnis perusahaan dan kebijakan operasinya.

9) Usaha yang ditawarkan memiliki permintaan pasar yang terbukti meemadai untuk produk dan jasa yang dikembangkan oleh franchisor.

10) Memiliki sekumpulan standar arsitektur dan kriteria pemilihan lokasi yang seragam.

11) Memahami pemahaman yang tepat terhadap pesaing.

12) Memiliki hubungan dengan pemerintah, lembaga keuangan, developer, dan sumber daya penting lainnya.

13) Memiliki sistem penyaringan dan rekruitmen franchisee.

14) Memiliki kemampuan dan fasilitas riset dan pengembangan produk dan jasa baru.

15) Memiliki sistem pelaporan dan pencatatan yang efektif.

16) Memiliki sistem komunikasi yang mempermudah dialog terbuka dan berkesinambungan dengan franchisee.

17) Memiliki program advertising, pemasaran dan kehumasan di tingkat lokal, daerah, nasional bahkan internasional.

\section{Penutup}

Franchising adalah suatu sistem idustri khususnya pemasaran yang berkisar pada perjanjian sah antara dua pihak yang salah satunya (franchisee) diberi hak istimewa untuk menjalankan bisnis sebagai pemilik pribadi, tapi dengan syarat perusahaan yang dijalankan menurut metode dan terminologi yang dispesifikasikan oleh pihak yang lain (franchisor).

Franchise merupakan salah satu alternatif dalam melakukan kegiatan bisnis insdustri makanan . Kepemilikan franchise menawarkan kemungkinan bagi wirausaha untuk mengurangi resiko keseluruhan dalam memulai suatu bisnis. Franchise terbukti tetap eksis dalam masa krisis.

Franchising bukanlah satu-satunya pilihan ideal untuk calon wirausaha karena faktor kritisnya berbeda-beda untuk setiap orang,

*) Drs. Endang Supardi, M.Si. Dosen Jurusan Pendidikan Ekonomi FPIPS-UPI

**) Sri Mulyati, S.Pd, Stap Penganjar Bidang Studi IPS SLTP 2 Lembang 
tergantung pada tujuan dan keadaan pribadi orang tersebut. Sebelum memutuskan franchising sebagai pilihannya, semua calon wirausaha harus memahami kelebihan dan kekurangan franchising tersebut.

Mengevaluasi kesempatan usaha franchise bagi calon wirausaha sangatlah penting sehingga calon wirausaha tersebut tidak salah dalam menjatuhkan pilihannya kepada usaha franchise untuk altenatif bisnisnya. Oleh karemna itu calon wirausaha juga harus harus memahami ciri-ciri franchising-franchising yang memenuhi persyaratan dan trik-trik khusus untuk mengembangkan usaha tersebut.

Kelebihan usaha franchise antara lain pelatihan, bantuan finansial dan keuntungan operasi. Sedangkan kekurangan usaha franchise meliputi biaya franchise, pembatasan pengoperasian bisnis dan hilangnya kebebasan.

Hal yang penting bagi franchisee yang potensial untuk mengingat bahwa baanyak gambaran keuangan yang ditampilkan dalam paket informasi dari franchisor hanya berupa perkiraan saja. Sedangkan klaim atas laba menjadi olebih umum, franchisor yang berprestasi menjadi lebih hati-hati untuk tidak berbuat salah dalam menyajikan apa yang dapat diperoleh oleh franchise yang berkaitan dengan penjualan, pendapatan kotor dan laba.

\section{Daftar Pustaka}

Buchari Alma, DR, 1998, Pengantar Bisnis, Alfabeta-Bandung.

Geoffrey G, Meredith et,al, 1987, Kewirausahaan Teori dan Praktek, PPM, Pustakan Binaman Pressindo, Jakarta.

Justin G. Longenecker, Carlos W. Moore, J. William Petty, Kewirausahaan (Manajemen Usaha Kecil), Salemba EmpatJakarta.

http://www.smfranchise.com

Mingguan Ekonomi dan Bisnis, KONTAN, Edisi 15 Juli 2002, Edisi 29 April 2002, edisi 8 April 2002.

Majalah Warta Ekonomi, Edisi No.04/XV/26 Februari 2003.

Rodney Overton, Starting A New Business (Memulai Usaha Baru), Elex Media Komputindo, Gramedia Jakarta.

Roger. D. Blackwell, Prom Mind To Market (Dari Pikiran ke Pasar), Elex Media Komputindo, Gramedia Jakarta. 